\title{
I.O. Дудченко
}

\section{РИЗИК РОЗВИТКУ АРТЕРІАЛЬНОЇ ГІПЕРТЕНЗІЇ ЗАЛЕЖНО ВІД ПОЛІМОРФІЗМУ ТЗ93С ГЕНА $\alpha$-СУБОДИНИЦІ G-БІЛКА}

Медичний інститут Сумського державного університету

Резюме. За даними іноземних дослідників, поліморфізм Т393С гена $\alpha$-субодиниці G-білка (rs7121) впливає на діяльність симпато-адреналової системи та ризик розвитку артеріальної гіпертензії (АГ). Також існують дані щодо залежності проявів цього поліморфізму від наявності супутніх чинників ризику. Проте ці дані $\epsilon$ суперечливими, що пояснюється етнічною приналежністю пацієнтів. В Україні досліджень 3 даної проблеми не проводилось. Нами досліджено 166 хворих на АГ та 90 практично здорових осіб. Визначення поліморфізму проводилося за допомогою полімеразної ланцюгової реакції з подальшим аналізом рестрикційних фрагментів. У результаті дослідження не виявлено статистично вірогідної різниці в розподілі генотипів Т393Т, Т393С, С393С у пацієнтів із АГ та практично здорових осіб ( $>0,05)$. Ризик розвитку АГ у носіїв генотипів Т393Т + Т393С відносно носіїв генотипу С393С достовірно не відрізнявся (ВШ $=1,44,95 \%$ ДІ 0,74-2,80; p=0,283). При аналізі впливу тютюнокуріння на прояви поліморфізму T393C гена $\alpha$-субодиниці G-білка також не виявлено статистично достовірної різниці ( $>00,05)$. Поліморфізм T393C гена $\alpha$-субодиниці G-білка не впливав на ризик розвитку артеріальної гіпертензії.

Ключові слова: артеріальна гіпертензія, поліморфізм гена, G-білок.
Вступ. Проблема розвитку артеріальної гіпертензії (АГ) вже тривалий час знаходиться в центрі уваги науковців всього світу. Більше ніж за сторіччя наукових досліджень накопичено безліч даних стосовно етіології та патогенезу цього захворювання, виникнення ускладнень, створено та впроваджено у практику диференційна тактика лікування. Однак постійне зростання розповсюдженості АГ, а також тяжкість органічних уражень та їх функціональних проявів, вимагає постійного вдосконалення вже існуючих та пошуку нових заходів запобігання виникненню АГ.

Аналіз останніх публікацій свідчить про намагання вирішити це питання шляхом визначення генетичної детермінованості АГ, а саме - залежності від поліморфізму генів, що кодують вазоконстрикторні та вазодилатаційні чинники, які залучені до контролю за рівнем артеріального тиску (АТ) у людини. В Україні проводилося дослідження взаємозв'язку АГ із поліморфізмом генів: ангіотензинперетворюючого ферменту, рецепторів ангіотензину II, ангіотензиногену, ендотеліальної NO-синтази, рецептора активато-

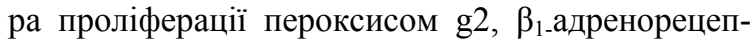
тора [1-4]. Отримані результати досліджень $€$ суперечливими та потребують подальшого вивчення.

Одну з основних ланок патогенезу АГ займає симпато-адреналова система, а саме Gбілокзв'язані рецептори, що відіграють велике значення для серцево-судинного гомеостазу у фізіологічних і патофізіологічних умовах $[5,6]$. Дія на дані рецептори агоністів (норадреналіну та адреналіну) призводить до активації G-білків (а саме $\mathrm{G}_{\mathrm{s}}$-білка, що активує аденілатциклазу) та вторинних месенджерів (циклічний аденозинмонофосфат (цАМФ)) [7, 8].G-білок має три субодиниці: $\alpha, \beta, \gamma$. Перелічені субодиниці G-білка та гуанозиндифосфат міцно зв'язані між собою, коли G-білокзв'язані рецептори знаходяться у стані спокою. Дія агоніста призводить до пору(C) I.O. Дудченко, 2014 шення даного зв'язку, змінюється структура $\alpha$ субодиниці, та, таким чином, молекула гуанозиндифосфату замінюється на молекулу гуанозинтрифосфату, що супроводжується трансдукцією рецептора. Відбувається активація аденілатциклази мембран ефекторних клітин, яка каталізує синтез цАМФ і через систему цАМФ-залежних протеїнкіназ стимулюються внутрішньоклітинні біохімічні процеси (роботу К-Са насосів). Після гідралізації гуанозинтрифосфату до гуанозидинфосфату $\alpha$-субодиниця інактивується, а структура G-білка відновлюється [9]. У контексті нашого дослідження слід врахувати наявність поліморфізму Т393C гена $\alpha$-субодиниці G-білка(GNAS1). Пацієнти з генотипом Т393Т мають підвищену активність аденілатциклази порівняно 3 носіями генотипу Т393С та С393С. Частота поліморфізму T393C гена GNAS1 в європеоїдної раси становить: для генотипу Т393Т - 34 \%, Т393С - $49 \%$, С 393С - 17 \% $[10,11]$. В Україні статистичних даних щодо частоти даного поліморфізму не існує.

Зазначені вище дані свідчать про важливу роль $\alpha$-субодиниці G-білка у функціонуванні симпато-адреналової системи, тому вивчення поліморфізму T393C гена GNAS1 носить перспективний характер у дослідженні ризику розвитку АГ. У світовій літературі існує незначна кількість досліджень з приводу взаємозв'язку АГ та поліморфізму T393C гена GNAS1, в яких отримані результати мають суперечливий характер [11-14].

Визначення поліморфізму Т393С гена GNAS1 серед хворих на АГ ймовірно відіграє роль у діагностиці додаткових чинників ризику розвитку та запобіганні виникненню АГ.

Мета дослідження. Провести аналіз асоціації поліморфізму T393C гена GNAS1 із ризиком розвитку АГ.

Матеріал і методи. У дослідженні брали участь 166 пацієнтів з верифікованим діагнозом АГ ІІ стадії (основна група) та 90 практично здорових осіб (група контролю), що проходили об- 
стеження та лікування на базі державних та комунальних закладів (КЗ) Сумської області: КЗ «Сумський обласний кардіологічний диспансер», К3 «Сумська міська клінічна лікарня № 1», К3 «Сумська міська поліклініка № 3», Сумська центральна районна клінічна лікарня, К3 «Сумський обласний клінічний госпіталь для IBBB» за період з 2010 по 2013 рр. Встановлення пацієнтам діагнозу АГ грунтувалося на критеріях Комітету експертів ВООЗ (1999) та рекомендаціях Українського товариства кардіологів (2004).

Для проведення дослідження 3 визначення поліморфізму генів проводили набір венозної крові в моновети об'ємом 2,7 мл у стерильних умовах, як антикоагулянт слугувала калієва сіль етилендіамінтетраоцтової кислоти $(11,7$ мM) ("Sarstedt", Німеччина). Кров заморожували та зберігали при температурі $20^{\circ} \mathrm{C}$. 3 цільної крові виділяли ДНК із використанням наборів DIAtom DNA Prep 100 («Isogene», Росія).

T393C поліморфізм 5-го екзону гена GNAS1 (rs7121) визначали методом полімеразної ланцюгової реакції (ПЛР). Наступним етапом було проведення аналізу довжини рестрикційних фрагментів. Для цього ампліфікували ділянку 5-го екзону вказаного гена за допомогою пари специфічних праймеp і в : п р я м г о ( 5'СTCCTAACTGACATGGTGCAA3' і зворотного $\left(\begin{array}{llllllllll}\mathrm{a} & \mathrm{n} & \mathrm{t} & \mathrm{i} & \mathrm{s} & \mathrm{e} & \mathrm{n} & \mathrm{s} & \mathrm{e}\end{array}\right)$ 5`TAAGGCCACACAAGTCGGGGT3' (виробництва "Metabion" (Німеччина)). ПЛР проводили в термоциклері GeneAmp PCR System 2700 ("Applied Biosystems", CША). Ампліфікація фрагмента 5-го екзону складалася з 30 циклів за допомогою рестриктази FokI ("Thermo Scientific", США) у буфері Tango. Якщо в 393-й позиції гена GNAS містився цитозин, ампліфікат, який складався з 345 пар основ, ген розщеплювався рестриктазою FokI на два фрагменти - 259 і 86 пар основ. У випадку заміни цитозину на тимін сайт рестрикції для FokI втрачався і утворювався один фрагмент розміром 345 пар основ. Після рестрикції ампліфікати розділяли в 2,5 \% агарозному гелі, що містив 10 мкг/мл бро- мистого етидію. Горизонтальний електрофорез $(0,13 \mathrm{~A} ; 200 \mathrm{~V})$ тривав упродовж 25 хв. Після електрофорезу проводили візуалізацію ДНК за допомогою трансілюмінатора ("Біоком", Росія).

Статистичний аналіз отриманих результатів проводили за допомогою програми SPSS Statistics-21. Достовірність різниці встановлювали за допомогою критерію $\mathrm{c}^{2}$. Різниці вважали вірогідними при $\mathrm{p}<0,05$.

Результати дослідження та їх обговорення. При проведенні генотипування за поліморфізмом T393C гена GNAS1 визначено його розподіл у групі практично здорових осіб та серед пацієнтів із АГ (табл.).

У групі контролю та у хворих на АГ частота генотипів Т393Т, Т393С та С393С достовірно не відрізнялась ( $\mathrm{p}=0,341$ за $\mathrm{c}^{2}$-критерієм).

При аналізі досліджуваних за генотипами Т393Т + Т393С відносно носіїв генотипу С393С також відсутня достовірна різниця в ризику розвитку АГ (ВШ=1,44, 95\% ДІ 0,74-2,80; p=0,283).

Для визначення впливу тютюнокуріння на прояв поліморфізму T393C гена GNAS1 проведено опитування пацієнтів та практично здорових осіб. У групі контролю виявили 63 (70,0 \%) особи, що курять, 27 (30,0 \%) - не курять. Серед пацієнтів основної групи - 23 (13,9\%) - курять, 143 $(86,1 \%)$ - не курять. Розподіл за генотипом представлений на рисунку.

У досліджуваних групах достовірної відмінності у розподілі генотипів залежно від тютюнокуріння не виявлено ( $>0,05$ за с $\mathrm{c}^{2}$-критерієм).

У нашому дослідженні не виявлено взаємозв'язку між поліморфізмом T393С гена GNAS1 та ризиком розвитку АГ. Ці дані співзвучні 3 результатами, отриманими Yamamoto M. et al. (2004) [13]. На відміну від даних Jia H. et al. (1999), які визначили, що частота С-алеля в пацієнтів із АГ та у групі контролю з нормальним АТ відрізнялась (С-алель, Т-алель - $51 \%$, $49 \%$ та $58 \%, 42 \%$ відповідно) $(\mathrm{p}=0,02)$ [12].

За даними Abe M. et al. (2002), при дослідженні у більш ніж 2000 жителів Японії взаємо-

Таблиця

\section{Частота генотипів за поліморфізмом T393C гена GNAS1 у хворих на артеріальну гіпертензію} та практично здорових осіб

\begin{tabular}{|c|c|c|c|c|c|}
\hline \multirow{2}{*}{ Ген } & \multirow{2}{*}{ Генотип } & \multicolumn{2}{|c|}{ Хворі на АГ } & \multicolumn{2}{|c|}{ Практично здорові } \\
\hline & & $\mathrm{n}$ & y $\%$ & $\mathrm{n}$ & y $\%$ \\
\hline \multirow{4}{*}{ GNAS1 } & T3939T & 63 & 38,0 & 28 & 31,1 \\
\hline & T393C & 80 & 48,2 & 44 & 48,9 \\
\hline & C393C & 23 & 13,9 & 18 & 20,0 \\
\hline & Разом & 166 & 100 & 90 & 100 \\
\hline $\mathrm{c} 2$ & \multicolumn{5}{|c|}{5,150} \\
\hline $\mathrm{p}$ & \multicolumn{5}{|c|}{0,341} \\
\hline
\end{tabular}

Примітка. * p- статистична значимість відмінностей між порівнювальними групами 


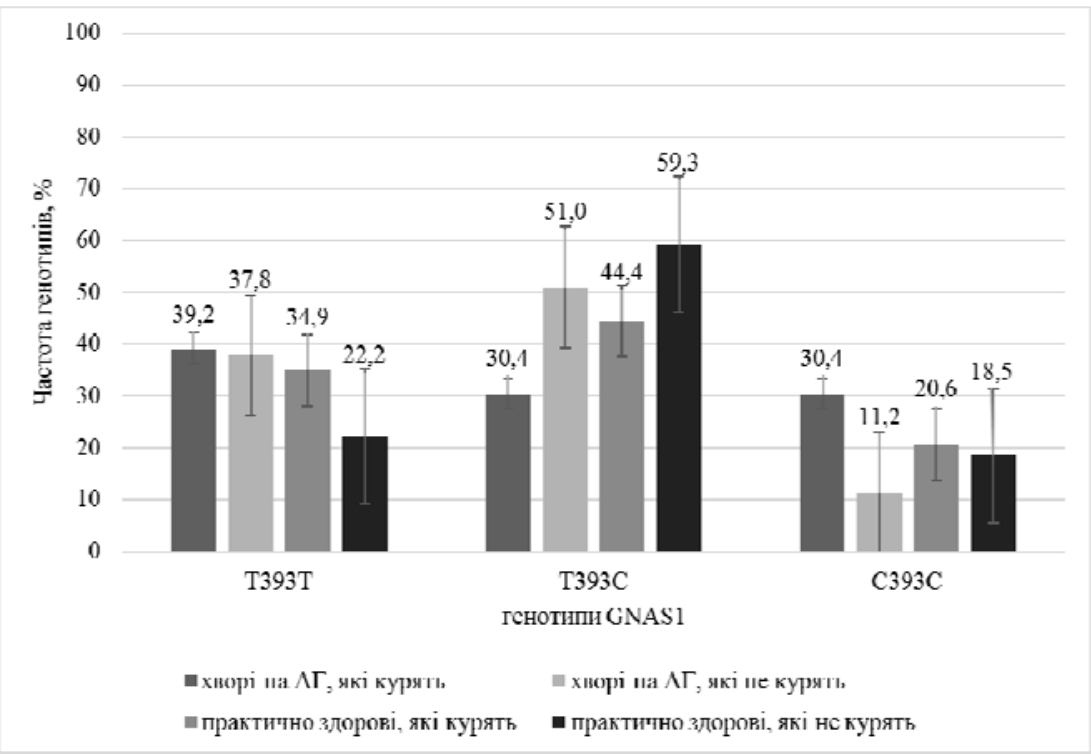

Рис. Розподіл генотипів поліморфізму гена GNAS1залежно від наявності артеріальної гіпертензії та тютюнокуріння

зв’язку між GNAS1 та рівнем АT виявлено значну асоціацію поліморфізму з АГ у осіб, що не курять ( $\mathrm{p}=0,0028)$. Крім того, аналіз асоціації куріння з АГ показав наявність взаємозв'язку в носіїв генотипів Т393Т та Т393C ( $\mathrm{p}=0,0051)$, чого не спостерігалось у носіїв генотипу С393С [15]. Результати дослідження Chen Y. et al. (2003) підтвердили, що в носіїв алеля Т393 частіше трапляється АГ, ніж у носіїв алеля С393. Також виявлено, що носії алеля Т393 мають вищий рівень АТ, ніж гомозиготи С393 в осіб, що не схильні або вживають малу кількість алкоголю $(\mathrm{p}=0,0084)$. В осіб, які вживають велику кількість алкоголю, спостерігалася протилежна тенденція [14]. Проте результати нашого дослідження не підтверджують залежності від тютюнокуріння. Ризик розвитку АГ залежно від Т393С поліморфізму гена GNAS1 вивчено нами в Україні вперше.

\section{Висновок}

Встановлено, що достовірна різниця в розподілі генотипів Т393Т, Т393C, C393С гена GNAS1 серед пацієнтів із артеріальною гіпертензією та практично здорових осіб відсутня навіть, при аналізі впливу додаткових чинників ризику - тютюнокуріння. Отже, визначення цього поліморфізму гена GNAS1 не відіграє значної ролі при аналізі ризику розвитку артеріальної гіпертензії.

Перспективи подальших досліджень. Зважаючи на те, що поліморфізм T393С гена GNAS1 $\epsilon$ асоційований iз функціонуванням симпатоадреналової системи, через G-білок зв'язані рецептори, доцільним є вивчення впливу даного поліморфізму на ефективність лікування $\beta$ адреноблокаторами хворих на АГ.

\section{Література}

1. Досенко В.С. Роль алельного поліморфізму генів ендотеліальної NO-синтази та протеасоми в патогенезі серцево-судинних захворювань: молекулярногенетичні аспекти: дис. на здобуття наук. ступеня д-ра мед. наук: 14.03.04 / Досенко Віктор Свгенович. - К., 2006. $-310 \mathrm{c}$.
2. Целуйко В.И. Влияние типа I/D полиморфизма гена ангиотензинпревращающего фермента на клиническое течение гипертонической болезни / В.И. Целуйко, О.В. Палецкая // Укр. кардіол. ж. - 2008. - № 1. C. 26-31.

3. Частота поліморфізму генів ангіотензинперетворювального ферменту (I/D), рецептора ангіотензину II першого типу (А1166C), ендотеліальної NO-синтази (T894G), рецептора PPAR- $\gamma 2$ (Pro12Ala), $\beta 1$ адренорецептора (Arg389Gly) у хворих на артеріальну гіпертензію у західно-українській популяції (Буковина) [Електронний ресурс] / Л.П. Сидорчук, К.М. Амосова, Р.А. Волков [та ін.] // Актуальні проблеми акушерства і гінекології, клінічної імунології та медичної генетики (Збірник наукових праць). - 2009. Випуск 16. - С.346-362. - Режим доступу до журналу : www.nbuv.gov.ua/portal/chem_biol/Apagki/V_16/346361.pdf.

4. Роль полиморфизма гена ангиотензинпревращающего фермента в реализации влияния суточного профиля артериального давления на формирование гипертрофии левого желудочка у больных с артериальной гипертензией / Г.В. Дзяк, Н.Г. Горовенко, Т.В. Колесник [и др.] // Укр. кардіол. ж. - 2007. - № 6. - С. 31-39.

5. Impact of GPCRs in clinical medicine: genetic variants and drug targets / P.A. Insel, C.M. Tang, I. Hahntow [et al.] // Biochim. Biophys. Acta. - 2007. - № 1768. P. 994-1005.

6. Regulation of $\mathrm{G}$ protein-coupled receptor signalling: focus on the cardiovascular system and regulator of $\mathrm{G}$ protein signalling proteins / M.C. Hendriks-Balk, S.L. Peters, M.C. Michel [et al.] // Eur. J. Pharmacol. - 2008. № 585. - P. 278-291.

7. Association analyses of adrenergic receptor polymorphism with obesity and metabolic alteration / J.J. Lima, H. Feng, L. Duckworth [et al.] // Metabolism. - 2007. Vol. 56, № 6. - P. 757-765.

8. Genetic polymorphisms of human beta-adrenergic receptor genes and their association with obesity / Z.Q. Liu, W. Mo, Q. Huang [et al.] // Zhong Nan Da Xue Xue Bao Yi Xue Ban. - 2007. - Vol. 32, № 3. - P. 359-367.

9. Eglen R.M. Emerging concepts of guanine nucleotidebinding protein coupled receptor (GPCR) function and implications for high throughout screening / R.M. Eglen, R. Bosse, T. Reisine // Assay. Drug. Dev. Tech. - 2007. № 5. - P. 425-451.

10. Association between beta-adrenergic receptor polymorphisms and their G-protein-coupled receptors with body mass index and obesity in women: a report from the 
NHLBI-sponsored WISE study / S.G. Terra, S.P. McGorrey, R. Wu [et al.] // Int. J. Obes. (Lond). 2005. - Vol. 29, № 7. - P. 746-754.

11. Association of GNAS1 gene variant with hypertension depending on smoking status / M. Abe, J. Nakura, M. Yamamoto [et al.] // Hypertehsion. - 2002. - № 40. P. 8-14.

12. Association of the Gs $\alpha$ gene with essential hypertension and response to $\beta$-blockade / H. Jia, A.D. Hingorani,
P. Sharma [et al.] // Hypertension. - 1999. - № 34. P. 8-34.

13. Association of a GNAS1 gene variant with hypertension and diabetes mellitus / M. Yamamoto, M. Abe, J.J. Jin [et al.] // Hypertens. Res. - 2004. - № 27. - P. 919-924.

14. Association of the GNAS1 gene variant with hypertension is dependent on alcohol consumption / Y. Chen, J. Nakura, J.J. Jin [et al.] // Hypertens. Res. - 2003. № 26. - P. 439-444.

\section{РИСК РАЗВИТИЯ АРТЕРИАЛЬНОЙ ГИПЕРТЕНЗИИ В ЗАВИСИМОСТИ ОТ ПОЛИМОРФИЗМАТЗ93С ГЕНА $\alpha$-СУБЪЕДИНИЦЫ G-БЕЛКА}

\section{И.А. Дудченко}

Резюме. По данным зарубежных исследователей полиморфизм Т393С гена $\alpha$-субъединицы G-белка (rs7121) влияет на работу симпато-адреналовой системы и риск развития артериальной гипертензии (АГ). Также существуют данные относительно зависимости проявлений этого полиморфизма от сопутствующих факторов риска. Но эти данные противоречивы, что можно объяснить этническими различиями пациентов. В Украине исследований этой проблемы не проводилось. Нами исследовано 166 больных АГ и 90 практически здоровых лиц. Определение полиморфизма проводилось с помощью полимеразной цепной реакции с дальнейшим анализом рестрикционных фрагментов. В результате исследования не обнаружено статистически значимой разницы в распределении генотипов Т393Т, Т393С, С393С у пациентов с АГ и практически здоровых лиц (p>0,05). Риск развития АГ у носителей генотипов Т393Т + Т393С относительно носителей генотипа С 393 С достоверно не отличается (ОШ $=1,44,95 \%$ ДИ $0,74-$ $2,80 ; \mathrm{p}=0,283)$. При анализе влияния курения на проявления полиморфизма T393C гена $\alpha$-субъединицы G-белка не обнаружено статистически значимой разницы (p>0,05). Полиморфизм T393C гена $\alpha$-субъединицы G-белка не влиял на риск развития АГ.

Ключевые слова: артериальная гипертензия, полиморфизм гена, G-белок.

\section{RISK OF ARTERIAL HYPERTENSION DEVELOPMENT DUE TO T393C GENE POLYMORPHISM OF $\alpha$-SUBUNIT OF G-PROTEIN}

\section{I.A. Dudchenko}

Abstract. According to foreign researchers, T393C gene polymorphism of $\alpha$-subunit of the G-protein (rs7121) affects the sympathetic-adrenal system and the risk of hypertension. There are also data on the dependence of the manifestations of this polymorphism on the associated risk factors. However, these data are contradictory, which may be explained by ethnic differences in patients. In Ukraine there were no studies on this issue. We have studied 166 hypertensive patients and 90 healthy individuals. Determination of the polymorphism was performed by polymerase chain reaction with subsequent analysis of restriction fragments. The study found no statistically significant difference in the distribution of genotypes T393T, T393C, C393C in patients with hypertension and healthy subjects ( $p>0,05)$. The risk for hypertension in carriers of genotypes T393T + T393C relatively to C393C genotype was not significantly different $(\mathrm{OR}=1,44,95 \%$ CI $0,74-2,80$; $\mathrm{p}=0,283$ ). During the analysis of the effect of smoking on the manifestations of T393C gene polymorphism $\alpha$-subunit of the G-protein, no statistically significant difference were found ( $p>0,05)$. T393C gene polymorphism of $\alpha$-subunit of G-protein did not affect the risk of hypertension.

Key words: hypertension, gene polymorphism, G-protein.

Medical Institute of State University (Sumy) 